\title{
Impact of salinity on the performance and microbial community of anaerobic ammonia oxidation (Anammox) using 16S rRNA High- throughput Sequencing technology
}

Wang X.D., Wang Y.Y.*, Song S.K., Wang W.G., Wu M. and Wang D.L.

State Key Laboratory of Pollution Control and Resources Reuse, College of Environmental Science and Engineering, Tongji University, Siping Road, Shanghai 200092, P. R. China

Received: 06/12/2016, Accepted: 14/02/2017, Available online: 09/10/2017

*to whom all correspondence should be addressed: yayi.wang@tongji.edu.cn; wyywater@126.com

\section{Abstract}

Salinity is a key environmental factor for the successful application of anammox technology in wastewater treatment, because it impacts the activity and the community structure of anammox bacteria. In this study, the changes in activity and population shifts of an anammox system response to the elevated salt stress $(0,5$, 10, 20, 30 and $40 \mathrm{~g} \mathrm{NaCl} / \mathrm{L}$ ) were studied.

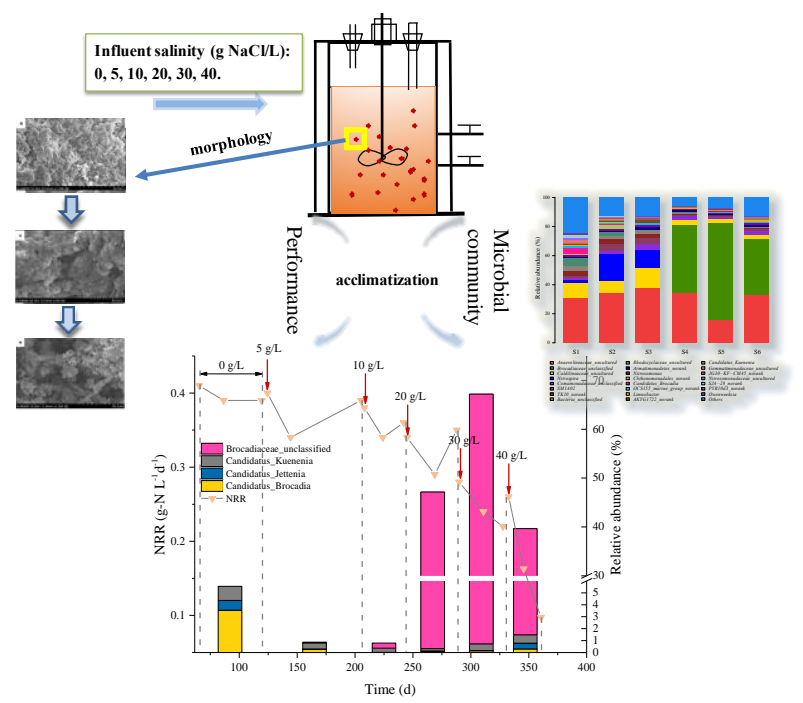

The results show that the anammox reactor performed effectively even at $30 \mathrm{~g} \mathrm{NaCl} / \mathrm{L}$ salinity after an appropriate acclimatization. The nitrogen removal rate maintained at $0.28 \mathrm{~g} \mathrm{~N} \mathrm{~L}^{-1} \mathrm{~d}^{-1}$ with the nitrogen removal efficiency of $76 \%$, though the high environmental salinity might inhibit the anammox growth in the long-term operation. 16S rRNA high-throughput sequencing results revealed that $\mathrm{Ca}$. Brocadia, Ca. Jettenia and Ca. Kuenenia were the dominant anammox bacteria at all salinities. Ca. Brocadia and Ca. Jettenia were quite sensitive to salinity, and $5 \mathrm{~g} \mathrm{NaCl} / \mathrm{L}$ dosing could cause a sharp decline in their abundance. Nevertheless, these three anammox genus finally survived in the system with a steady specific anammox activity of 0.13 g $\mathrm{N}$ g VSS${ }^{-1} \mathrm{~d}^{-1}$. Specially, a novel cluster, Brocadiaceae_unclassified, which possibly belongs to anammox bacteria, became the dominant genus at the salinity over $20 \mathrm{~g} \mathrm{NaCl} / \mathrm{L}$ and likely contributed partially to the nitrogen removals. Our findings elucidated the inherent link between community dynamics and anammox system performance and stability under salty environment, and proved that anammox technologies can be an effective technology for treatment of saline ammonia-rich wastewater.

Keywords: Salinity; anammox bacteria; nitrogen removal; 16S rRNA high-throughput

\section{Introduction}

The discharge of wastewater containing high nitrogen can lead to eutrophication which causes the excessive growth of algal, and thus posing a great threat to the ecological health of water resources (Van Hulle et al., 2010). In most modern wastewater treatment plants, nitrogen in 
wastewater is biologically removed by nitrification and denitrification processes, which requires much electric energy to create aerobic conditions for bacterial nitrification as well as organic carbons like methanol or ethanol to remove nitrate by bacterial denitrification (Kartal et al., 2010). Anaerobic ammonia oxidation (anammox), termed as autotrophic nitrogen removal process, is a cost effective and environment friendly nitrogen removal technology, which offers a sustainable alternative to remove nitrogen with less demand of oxygen supply and no extra carbon sources (Kartal et al., 2006). In anammox processes, ammonium is oxidized using nitrite as electron acceptors and conserves energy for $\mathrm{CO}_{2}$ fixation (Strous et al., 1999). Although anammox technology possesses significant advantages compared to conventional nitrogen removal technologies, the widespread implementation of anammox may be hindered by long term start-up because of the low growth rate (doubling time of approximately $15 \mathrm{~d}$ ), high temperature requirement, and high sensitivities to inhibitory matters presented in wastewater such as organic matters and salt (Jin et al., 2012; Van Hulle et al., 2010; Xing et al., 2015).

From a practical perspective, salinity is an important parameter for wastewater treatment as the high salt concentration could inhibit microorganism growth by destroying the cell-wall and enzymes of bacteria, resulting in cell plasmolysis and losing activity of the cells (Uygur, 2006). Actually, many industrial wastewaters, such as petroleum and pharmaceutical industries, seafood processing, landfill leachate and leather industry, which are rich in ammonium, are also characterized by high salt concentrations (total salinity excesses $10 \mathrm{~g} \mathrm{NaCl} / \mathrm{L}$ ) (Yi et al., 2011). Moreover, due to the shortage of fresh water resources, many coastal cities generally use sea water as municipal water flushing lavatories and sprinkling street, which would engender a large volume of saline sewage (Chen et al., 2003). Salt impacts on N-removals have been previously investigated, and salt stress could be commonly alleviated by two strategies: i) utilization of halophilic microbial consortia from brackish sediments (Din Er and Kargi, 2001) and ii) gradual acclimatization of freshwater microorganism to saline conditions (Panswad and Anan, 1999). These strategies may also be suitable for anammox processes to resist salty environment.
Until now, five genera of candidate anammox bacteria have been provisionally proposed in planctomycets, i.e. Candidatus Brocadia, Ca. Kuenenia, Ca. Scalindua, Ca. Anammoxoglobus, and Ca. Jettenia (Awata et al., 2015). Among them, only "Scalindua" genus has been detected in natural saline ecosystems (Thamdrup and Dalsgaard, 2002). As for the first salt stress alleviation strategy, Nakajima et al., (2008) enriched Ca. Scalindua from Ago Bay in Japan using a continuous culture system, providing a possibility of the salty wastewater treatment by anammox technologies. In most cases, the second strategy that gradual adaptation of fresh anammox species to saline condition is applied to obtain anammox bacteria that could endure salty conditions (Bassin et al. 2012; Kartal et al., 2006). For example, Kartal et al., (2006) seeded anammox bacteria from a freshwater system, and successfully adapted the microorganisms to high salinity level of $30 \mathrm{~g} / \mathrm{L}$; the seed sludge consisted of $50 \%$ of Candidatus "Kuenenia stuttgartiensis" and $50 \%$ of Candidatus "Scalindua wagneri", and in a salt adapted sludge, the freshwater anammox species Candidatus "Kuenenia stuttgartiensis" was the dominant population. Likewise, in a Sharonanammox system, a nitrogen loading rate (NLR) of $600 \mathrm{~g} \mathrm{~N}$ $\mathrm{m}^{-3} \mathrm{~d}^{-1}$ was maintained even at a salinity of $15 \mathrm{~g} \mathrm{NaCl} / \mathrm{L}$ without a remarkable change in anammox activities (Dapena-Mora et al., 2006). Later, Liu et al., (2009) reported that, in an anammox fixed-bed reactor with a non-woven biomass carrier, freshwater anammox sludge can be applied in the treatment of saline wastewater, and the nitrogen removal rate (NRR) remained at $1.7 \mathrm{~kg} \mathrm{~N} \mathrm{~m}^{-3} \mathrm{~d}^{-1}$ with the salinity up to $30 \mathrm{~g} \mathrm{NaCl} / \mathrm{L}$ after extended acclimatization. They found the survived anammox bacteria was a freshwater anammox bacterium KU2. However, due to the different seed sludges in different studies, the information on microbial structure shift along with increasing salinity is still limited, which however is most important to anammox reaction performance. In order to develop environmentally conscious operational practices and get a better understanding of biological $\mathrm{N}$ removal performance while treating saline wastewater by anammox processes, studies about the dynamics of the microbial community structure in anammox systems is urgently required.

In this study, a sequential batch reactor (SBR) was operated for 361 days to investigate the effects of increasing salinity 
$(0,5,10,20,30$ and $40 \mathrm{~g} \mathrm{NaCl} / \mathrm{L})$ on anammox performance and sludge physical morphology. In particular, the microbial community dynamic of anammox bacteria response to the increasing salt stress was comprehensively evaluated using 16S rRNA high-throughput sequencing technique that has overwhelming superiority on profiling complex bacteria community for its unprecedented sequencing depth (GLENN, 2011). We aim to elucidate the relationship between anammox performance and evolution of microbial community structure for the stable and effective application of anammox processes in the industrial field.

\section{Materials and Methods}

\subsection{Experimental set-up and operation strategy}

The experiment was conducted in a sealed SBR with a total volume of $2.5 \mathrm{~L}$ and an effective volume of $2 \mathrm{~L}$. The experimental temperature was maintained at $35^{\circ} \mathrm{C}$ using a thermostatic water bath, and the complete mixture was achieved using a mechanical stirrer. The SBR was operated with a cycle of $8 \mathrm{~h}$ which consisted of 5 minutes of feeding, 395 minutes of mixing, 55 minutes of settling, 5 minutes of drainage and 20 minutes of idle time. The ratio of effluent volume and reactor effective volume was kept at 0.5 , and the hydraulic retention time (HRT) was $16 \mathrm{~h}$.

Experimental data were collected over a period of 361 days and the entire experimental period was separated to seven phases according to the different salt concentrations (Table 1). At the start-up phase (day 1-60), the anammox sludge was acclimated for 60 days with a stepwise increased nitrogen loading rate (NLR) to get a stable nitrogen removal rate. Then, six-phase experiment was conducted with gradually increasing salt concentration.

Table 1. Operational phases and the corresponding influent characteristics of the lab-scale anammox reactor

\begin{tabular}{|c|c|c|c|c|c|}
\hline Phases & Time (d) & Salinity (g/L) & $\mathrm{NH}_{4}{ }^{+}-\mathrm{N}\left(\mathrm{mg}-\mathrm{N} \mathrm{L}^{-1}\right)$ & $\mathrm{NO}_{2}-\mathrm{N}\left(\mathrm{mg}-\mathrm{N} \mathrm{L}^{-1}\right)$ & $\operatorname{NLR}\left(\mathrm{g} \mathrm{N} \mathrm{L}^{-1} \mathrm{~d}^{-1}\right)$ \\
\hline start up & $1-60$ & 0 & $40 \rightarrow 140 \pm 20$ & $50 \rightarrow 190 \pm 20$ & - \\
\hline $\mathrm{I}$ & $61-123$ & 0 & $138 \pm 28$ & $186 \pm 17$ & $0.49 \pm 0.05$ \\
\hline II & $124-207$ & 5 & $131 \pm 17$ & $174 \pm 17$ & $0.46 \pm 0.06$ \\
\hline III & $208-244$ & 10 & $140 \pm 5$ & $179 \pm 8$ & $0.48 \pm 0.02$ \\
\hline IV & $245-289$ & 20 & $132 \pm 13$ & $165 \pm 24$ & $0.45 \pm 0.03$ \\
\hline $\mathrm{V}$ & $290-332$ & 30 & $111 \pm 17$ & $138 \pm 25$ & $0.37 \pm 0.06$ \\
\hline VI & $333-361$ & 40 & $95 \pm 25$ & $116 \pm 16$ & $0.32 \pm 0.07$ \\
\hline
\end{tabular}

\subsection{Seed anammox sludge and feeding media}

The seeding sludge was taken from another anammox reactor in our laboratory that had run steadily for over one year, keeping a maximum specific anammox activity (SAA) of $0.31 \pm 0.01 \mathrm{~g} \mathrm{~N} /$ (g VSS.d). Fluorescence in situ hybridization analysis revealed that the freshwater anammox species Candidatus "Kuenenia stuttgartiensis" dominated in the seeding sludge (probes EUB338 mix and KST-1275 were used).

The experimental reactor was fed synthetic medium with a ratio around 1.32 of nitrite to ammonium. The composition of the synthetic mediums was as follows: $40 \sim 140 \pm 20 \mathrm{mg}$ $\mathrm{NH}_{4}{ }^{+}-\mathrm{N} / \mathrm{L}, \quad 50 \sim 190 \pm 20 \mathrm{mg} \mathrm{NO}{ }_{2}^{-} / \mathrm{L}$ (range at different phases), $1.05 \mathrm{~g} / \mathrm{L} \mathrm{NaHCO}_{3}, 0.02 \mathrm{~g} / \mathrm{L} \mathrm{KH}_{2} \mathrm{PO}_{4}, 0.014 \mathrm{~g} / \mathrm{L} \mathrm{CaCl}_{2}$, $0.08 \mathrm{~g} / \mathrm{L} \mathrm{MgSO}_{4} \cdot 7 \mathrm{H}_{2} \mathrm{O}, 0.015 \mathrm{~g} / \mathrm{L} \mathrm{FeSO}_{4} \cdot 7 \mathrm{H}_{2} \mathrm{O}, 0.02 \mathrm{~g} / \mathrm{L}$ $\mathrm{Na}_{2}$ EDTA and $1 \mathrm{ml} / \mathrm{L}$ trace element solution $(0.018 \mathrm{~g} / \mathrm{L}$
$\mathrm{H}_{3} \mathrm{BO}_{3}, 0.262 \mathrm{~g} / \mathrm{L} \mathrm{CoCl}_{2} \cdot 2 \mathrm{H}_{2} \mathrm{O}, 0.312 \mathrm{~g} / \mathrm{L} \mathrm{CuSO}_{4} \cdot 5 \mathrm{H}_{2} \mathrm{O}, 0.538$ $\mathrm{g} / \mathrm{L} \quad \mathrm{ZnSO}_{4} \cdot 7 \mathrm{H}_{2} \mathrm{O}, 1.238 \mathrm{~g} / \mathrm{L} \quad \mathrm{MnCl}_{2} \cdot 4 \mathrm{H}_{2} \mathrm{O}, 0.238 \mathrm{~g} / \mathrm{L}$ $\mathrm{NiCl}_{2} \cdot 6 \mathrm{H}_{2} \mathrm{O}, 0.275 \mathrm{~g} / \mathrm{L} \mathrm{NaMoO} \cdot 2 \mathrm{H}_{2} \mathrm{O}, 7.5 \mathrm{~g} / \mathrm{L}$ EDTA).

\subsection{Scanning electron microscopy observation}

Morphological studies of the anammox flocs and granules were performed with scanning electron microscopy (SEM). The sludge samples were centrifuged for $5 \mathrm{~min}$ at a speed of $4000 \mathrm{r} / \mathrm{min}$ and subsequently fixed with a solution of $2.5 \%$ glutaraldehyde over night. Next, the sludge samples were washed in the phosphate buffer solution three times for $15 \mathrm{~min}$ each and fixed the samples for 60 to $120 \mathrm{~min}$ in a phosphate buffer solution with $1 \% \mathrm{OsO}_{4}$. After being washed in the phosphate buffer solution three times for 15 min each, the sludge samples were dehydrated for $15 \mathrm{~min}$ each in serially graded ethanol solutions of $50 \%, 70 \%, 80 \%$, $90 \%$ and $95 \%$. Then, the samples were shaded with gold 
and observed under the scanning electron microscopy (SUPERSCAN SSX-550).

\subsection{Analytical methods}

Ammonium $\left(\mathrm{NH}_{4}^{+}-\mathrm{N}\right)$, nitrite $\left(\mathrm{NO}_{2}^{-}-\mathrm{N}\right)$, nitrate $\left(\mathrm{NO}_{3}^{-}-\mathrm{N}\right)$ concentrations and VSS were measured according to standard methods (APHA, 1998). The maximum SAA was conducted according to Dapena-Mora et al (Dapena-Mora et al., 2004). The $\mathrm{pH}$ and ORP were measured by online probes (WTW pH3310 SenTix41 and WTW pH3310 SenTixORP respectively). The extracellular polymeric substance (EPS) was extracted using the heating method according to ref. (Adav and Lee, 2008). Carbohydrates in the EPS were taken by the anthrone method with a glucose standard. Proteins and Humus were determined with the Folin-Lowry method using bovine serum albumin as a standard (Liu and Fang, 2002).

\subsection{DNA extraction and PCR amplification}

The granular sludge sample was stored at $-80{ }^{\circ} \mathrm{C}$ for subsequent experiments. Total genomic DNA was extracted in duplicate from each sample using Power Soil DNA Isolation Kit (Sangon, China) according to the manufacture's instructions. Following extraction, the quality of the DNA was examined by $1 \%(w / v)$ agarose gel electrophoresis and concentration measured with NanoDrop spectrophotometer 2000 (Thermo Scientific, USA).

Polymerase chain reaction (PCR) of the V3-V4 region of the $16 \mathrm{~S}$ rRNA gene was amplified using bacterial primers $338 \mathrm{~F}$ (5'-ACT CCT ACG GGA GGC AGC AG-3') and 806R (5'-GGA CTA CHV GGG TWT CTA AT-3') (Claesson et al., 2010), with the reverse primer containing a $6 \mathrm{bp}$ barcode used to tag each sample. PCR amplifications were carried out in triplicate for each sample using $20 \mu \mathrm{L}$ reaction mixtures, containing $4 \mu \mathrm{L}$ of $5 \times$ PCR buffer, 10 ng of template DNA, $0.2 \mathrm{M}$ of each primer, $0.25 \mathrm{mM}$ of each dNTP, and $1 \mathrm{U}$ FastPfu polymerase (TransGen, China). The PCR conditions involved an initial denaturation step at $95{ }^{\circ} \mathrm{C}$ for $2 \mathrm{~min}$, followed by 30 cycles of $95{ }^{\circ} \mathrm{C}$ for $30 \mathrm{~s}, 55^{\circ} \mathrm{C}$ for $30 \mathrm{~s}$, and $72{ }^{\circ} \mathrm{C}$ for $30 \mathrm{~s}$ and ended with an extension step at $72{ }^{\circ} \mathrm{C}$ for 5 min in a GeneAmp 9700 thermocycler ( $A B I, U S A)$. The triplicate amplicons were pooled together, electrophoresed on $2 \%(\mathrm{w} / \mathrm{v})$ agarose gel, and recovered using an AxyPrep DNA Gel Extraction Kit (AXYGEN, China).
$2.616 S$ rRNA-based illumina library preparation, sequencing and data analysis

The purified amplicons were quantified by QuantiFluor-ST Fluorometer (Promega, USA), and then a composite sequencing library was constructed by combining quimolar ratios of amplicons from all samples. The resulting library was sent for paired-end sequencing $(2 \times 250 \mathrm{bp})$ on an Illumina Miseq platform at Majorbio Bio-Pharm Technology Co., Ltd. (Shanghai, China). Raw sequence data of this study have been deposited to the NCBI Sequence Read Archive, compared with sequences in the GenBank database.

Sequence data was then analyzed by the software of Trimmomatic and FLASH. To facilitate the comparison between different samples, the numbers of sequences were normalized to the same sequencing depths of 21,169 by MOTHUR program (Schloss et al., 2009). The effective sequences were clustered into operational taxonomic units (OTUs) at $97 \%$ sequence identity using Uearch program, and a representative sequence was then picked for each OUT by selecting the most abundant sequence in that OUT. These representative sequences were assigned to taxonomic classifications by Ribosomal Database Project (RDP) Classifier with a confidence threshold of 70\% (Wang et al., 2007). Additionally, the alpha diversity including rarefaction curves, Shannon and Simpson diversity index, species richness estimators of Chao, Ace and diversity coverage were calculated in MOTHUR for each sample.

\section{Results and discussion}

\subsection{Performance of anammox reactor in response to increasing salinity}

The performance of the anammox system over a period of 361 days is shown in Fig. 1. During phase I (day 61-123) when without salt addition, the anammox system reached a steady state with the nitrogen removal rate (NRR) of 0.40 $\mathrm{g} \mathrm{N} \mathrm{L}^{-1} \mathrm{~d}^{-1}$ and a nitrogen loading rate (NLR) of $0.49 \mathrm{~g} \mathrm{~N} \mathrm{~L}^{-1} \mathrm{~d}^{-1}$; also, both the ammonium and nitrite removal efficiencies achieved over $96 \%$.

After running for 123 days, $5 \mathrm{~g} \mathrm{NaCl} / \mathrm{L}$ was added into the influent in phase II (day 124-207). During the initial 20 days after the living environment changed from freshwater to salty water, the anammox bacteria activity was negatively impacted, leading to a slight decline in the NRR. 
Specifically, the NRR declined by $15 \%$ from $0.40 \mathrm{~g} \mathrm{NL}^{-1} \mathrm{~d}^{-1}$ (day 124) to $0.34 \mathrm{~g} \mathrm{NL}^{-1} \mathrm{~d}^{-1}$ (day 138), while the ammonium and nitrite removal efficiencies decreased to $83 \%$ and $86 \%$ respectively. Thereafter, the anammox system started to recover gradually. On day 155 , the reactor regained the stable nitrogen removal capacity; the NRR stabilized at 0.39 $\mathrm{g} \mathrm{NL}^{-1} \mathrm{~d}^{-1}$ with a constant NLR of $0.46 \mathrm{~g} \mathrm{NL}^{-1} \mathrm{~d}^{-1}$, indicating that anammox bacteria had adapted to the salt stress.
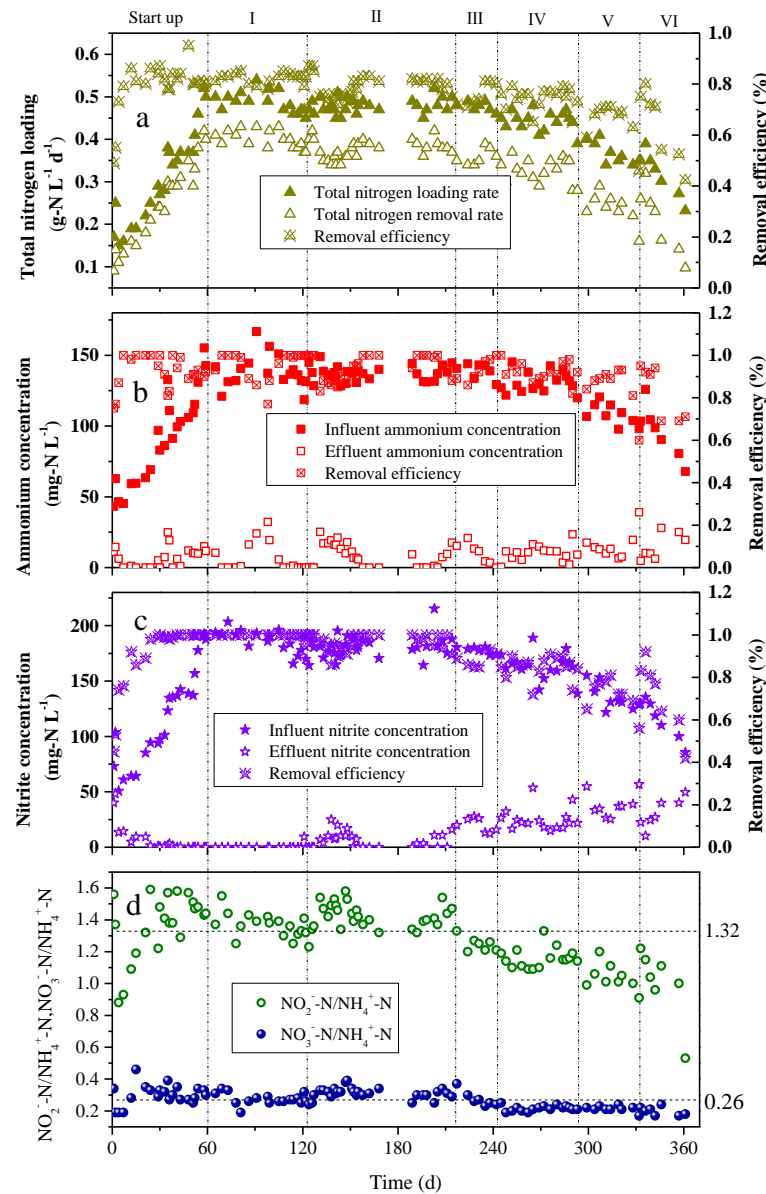

Figure 1. The long-term performance of the anammox reactor at different salinity levels $(a, b, c$ and $d$ represent the changes in the nitrogen load, ammonia concentration in the influent and effluent, nitrite concentration in the influent and effluent, and the stoichiometric parameters under different salinity levels, respectively. I ( $0 \mathrm{~g} \mathrm{NaCl} / \mathrm{L})$, II (5 g NaCl/L), III (10 g NaCl/L), IV(20 g NaCl/L), V (30 g

$$
\mathrm{NaCl} / \mathrm{L}), \mathrm{VI}(40 \mathrm{~g} \mathrm{NaCl} / \mathrm{L}))
$$

During phase III (day 208-244), the anammox reactor was fed with $10 \mathrm{~g} \mathrm{NaCl} / \mathrm{L}$. The nitrogen removal performance was decreased initially and then increased gradually. Similar to the case of $5 \mathrm{~g} \mathrm{NaCl} / \mathrm{L}$, the performance of nitrogen removal decreased greatly during the first 20 days that the ammonium removal efficiency declined from $96 \%$ (day 208) to $86 \%$ (day 224), and nitrite removal efficiency decreased from nearly $100 \%$ to $86 \%$. Nevertheless, after 20 days of acclimatization, the NRR was gradually stable at $0.38 \mathrm{~g} \mathrm{~N} \mathrm{~L}^{-1} \mathrm{~d}^{-1}$ under the NLR of $0.48 \mathrm{~g} \mathrm{~N} \mathrm{~L}^{-1} \mathrm{~d}^{-1}$.

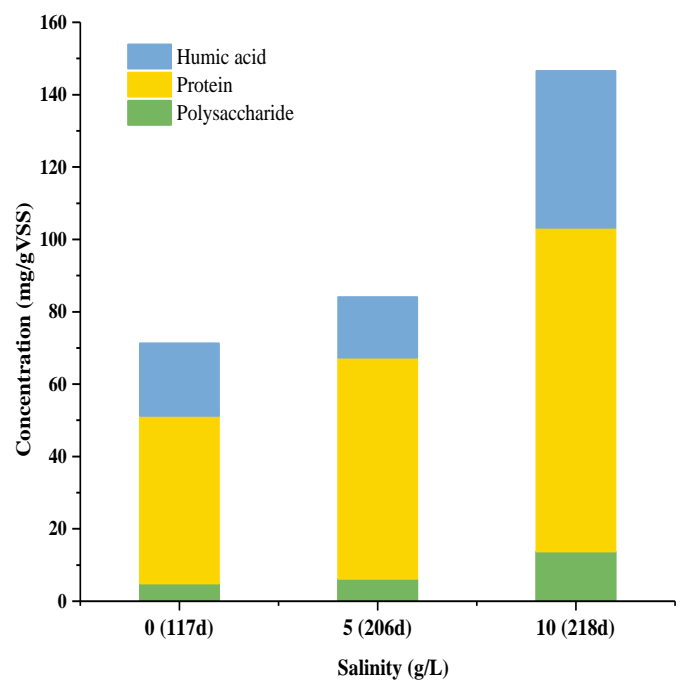

Figure S1 (supplementary). Variations in the EPS content and composition of the anammox sludge at different salinity levels (second row represent the number of days) When the influent salinity increased to $20 \mathrm{~g} \mathrm{NaCl} / \mathrm{L}$ during phase IV (day 245-289), the NLR was $0.45 \mathrm{~g} \mathrm{~N} \mathrm{~L}^{-1} \mathrm{~d}^{-1}$, but the NRR decreased to $0.29 \mathrm{~g} \mathrm{~N} \mathrm{~L}^{-1} \mathrm{~d}^{-1}$ with the ammonium removal efficiency of $89 \%$ and the nitrite removal efficiency of $83 \%$ on day 269 . At the end of phase IV, the TN removal efficiency improved with the NRR of $0.35 \mathrm{~g} \mathrm{NL}^{-1} \mathrm{~d}^{-1}$ upon the acclimatization to the salt stress. Then, the salt concentration was further increased to $30 \mathrm{~g} \mathrm{NaCl} / \mathrm{L}$ in phase V (day 290-332). The nitrogen removal capacity of the anammox reactor became poor. The NRR was $0.28 \mathrm{~g}$ $\mathrm{NL}^{-1} \mathrm{~d}^{-1}$ on day 290 , but decreased to $0.16 \mathrm{~g} \mathrm{NL}^{-1} \mathrm{~d}^{-1}$ on day 332 , confirming the high salt concentration had posed a negative effect on the anammox performance at a longterm operation.

After the salt concentration continued to increase to $40 \mathrm{~g}$ $\mathrm{NaCl}$ during phase $\mathrm{VI}$ (day 333-361), the reactor performance became worse. The NRR continuously decrease from $0.16 \mathrm{~g} \mathrm{NL}^{-1} \mathrm{~d}^{-1}$ to $0.10 \mathrm{~g} \mathrm{NL}^{-1} \mathrm{~d}^{-1}$ during a 29day span at the NLR of $0.32 \mathrm{~g} \mathrm{NL}^{-1} \mathrm{~d}^{-1}$. In this phase, the water density with high salinity was too high to maintain a good retention of the biomass, leading to a significant loss 
of the anammox bacteria inside the system. Consequently, the anammox reactor tended to collapse.

3.2 Evolution of microbial community structure with elevated salinity

\subsubsection{Bacterial richness and biodiversity variation}

Six sludge samples at different salinities, i.e., S1 (0 g $\mathrm{NaCl} / \mathrm{L}$ ), S2 (0 g NaCl/L), S3 (10 g NaCl/L), S4 (20 g NaCl/L), S5 (30 $\mathrm{g} \mathrm{NaCl} / \mathrm{L}$ ) and S6 (40 $\mathrm{g} \mathrm{NaCl} / \mathrm{L})$, were collected under a steady state of different phases. 16S rRNA highthroughput sequencing was conducted to elucidate the microbial community structure and dynamics of the studied anammox reactor with gradually elevated salinity.

The Shannon-Wiener curves obtained for each sludge sample are shown in Fig. 2. All the curves reached a plateau, suggesting that taxonomic diversity was almost fully exploited by the Miseq sequencing. Also, the coverage of each sample reached saturation over 0.99 (Table 2), indicating that the coverage degree is high enough to reflect the whole information about the bio-system.

The multiple $\alpha$-diversity indices are shown in Table 2 . When the salinity increased from 0 to $20 \mathrm{~g} \mathrm{NaCl} / \mathrm{L}$, Shannon and Simpson indices showed a decrease trend, corresponding well to the species richness indices (Ace and Chao), implying concomitant disappearance of some species. These results revealed that the selective pressure, including the osmotic environment and the settling properties, would wash out the bacterial species who could not survive in the salt stressful condition. Then, the species richness and diversity showed an increasing trend as the anammox system adapted to the elevated salinity from 20 to $40 \mathrm{~g} \mathrm{NaCl} / \mathrm{L}$.

Table 2. Alpha-diversity of the anammox sludge samples at different salinities

\begin{tabular}{cccccccc}
\hline \multirow{2}{*}{ Sample } & $\begin{array}{c}\text { Salinity } \\
\text { (g/L) }\end{array}$ & OTU & Ace Index & Chao Index & Coverage & Shannon Index & Simpson Index \\
\cline { 2 - 9 } & 0 & 525 & 584 & 600 & 0.995796 & 4.53 & 0.0316 \\
\hline S1 & 5 & 426 & 499 & 497 & 0.995843 & 3.81 & 0.0634 \\
\hline S3 & 10 & 382 & 421 & 425 & 0.997166 & 3.96 & 0.0462 \\
\hline S4 & 20 & 285 & 326 & 327 & 0.997355 & 2.61 & 0.2428 \\
\hline S5 & 30 & 322 & 399 & 398 & 0.995937 & 2.03 & 0.4462 \\
\hline S6 & 40 & 321 & 378 & 384 & 0.996788 & 3.19 & 0.1614 \\
\hline
\end{tabular}

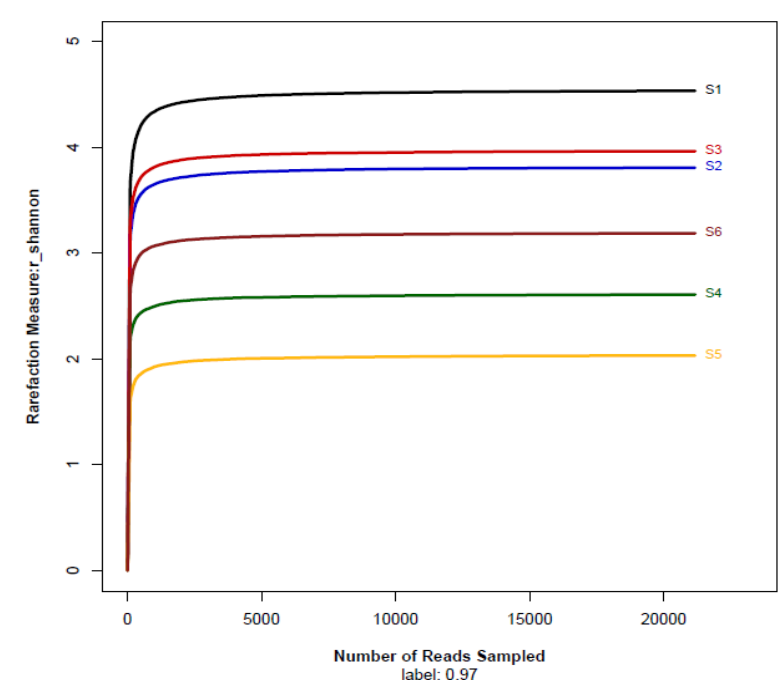

Figure 2. Shannon-Wiener curve of the anammox sludge sample $\mathrm{S} 1(0 \mathrm{~g} \mathrm{NaCl} / \mathrm{L}), \mathrm{S} 2$ (5 g NaCl/L), S3 (10 g NaCl/L), S4 (20 g $\mathrm{NaCl} / \mathrm{L})$, S5 (30 g NaCl/L), S6 (40 g NaCl/L) 

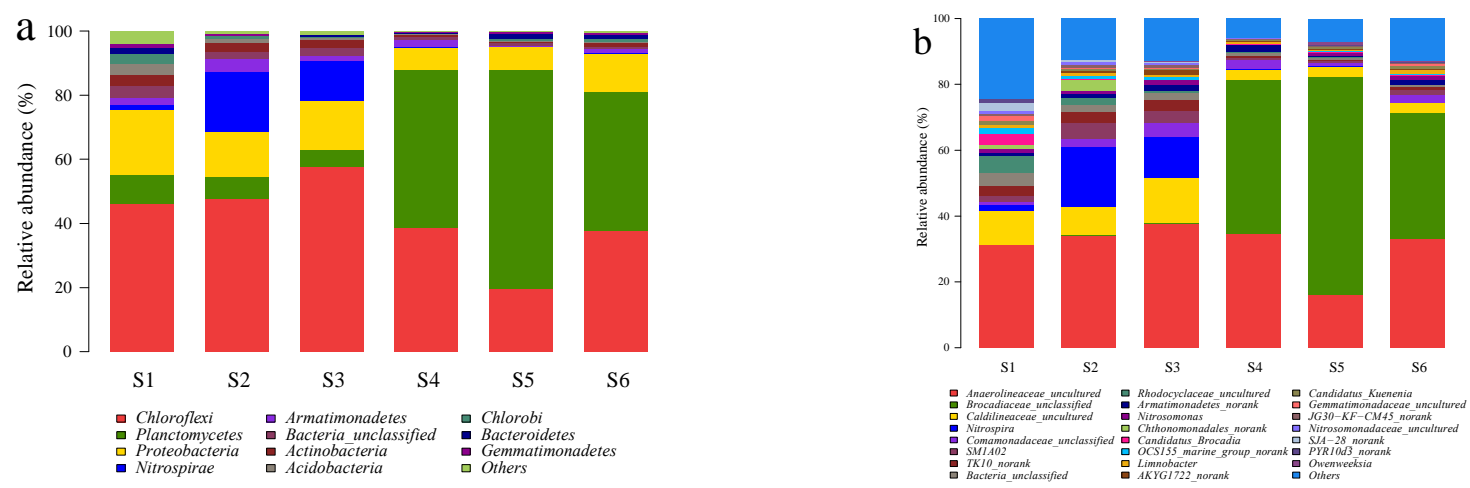

Figure 3. The bacterial flora distribution histogram at the level of "phylum" (a) and "genus" (b) of the anammox sludge samples S1 (0 g NaCl/L), S2 (5 g NaCl/L), S3 (10 g NaCl/L), S4 (20 g NaCl/L), S5 (30 g NaCl/L), S6 (40 g NaCl/L)

\subsubsection{Microbial community composition and dynamics}

The phylogenetic classification of effective bacterial sequences at the phylum level is summarized in Fig. 3a. Clearly, the bacterial community composition at different salinities was distinct. The dominant phyla across samples S1, S4, S5 and S6 were Chloroflexi, Planctomycetes and Proteobacteria. While, the dominant phyla in both samples of S2 and S3 were Chloroflexi, Planctomycetes, Proteobacteria and Nitrospira. It has been reported that Proteobacteria is the predominant phylum in various of full-scale $A / A / O$ systems, MBR systems, and the oxidation ditch processes (Hu et al., 2012). Venter et al., (2004) also found that Proteobacteria was dominant in the marine microbial community of the surface/sub-euphotic layers, and they concluded that salinity was closely related to Proteobacteria. Their findings can partially explain our findings that the relative abundance of Proteobacteria slightly decreased from $20.29 \%$ to $14.05 \%$ when the salinity addition increased from 0 to $5 \mathrm{~g} \mathrm{NaCl} / \mathrm{L}$, and remained at $12.09 \%$ with $40 \mathrm{~g} \mathrm{NaCl} / \mathrm{L}$ addition (Fig. 3a).

Notably, Chloroflexi, as a common sort of filamentous bacteria, was the most dominant phylum in the anammox system at 0,5 and $10 \mathrm{~g} \mathrm{NaCl} / \mathrm{L}$. They maintained at a relatively high abundance following to Planctomycetes at 20, 30 and $40 \mathrm{~g} \mathrm{NaCl} / \mathrm{L}$ salinities. However, the high amounts of Chloroflexi did not lead to the sludge bulking but promoted the granular process for the anammox flocs (Fig. 5b and c). Bossier and Verstraete, (1996) addressed that the filamentous organisms would provide a stabilizing backbone for the three-dimensional microbial aggregates called flocs. Chloroflexi is also ecologically significant and responsible for degradation of carbohydrates and cellular materials (Miura et al., 2007). Kindaichi et al., (2012) found that Chloroflexi was frequently detected in an anammox reactor, and they can scavenge organic matter derived from anammox bacterial cells to survive with the medium without external organic carbon compounds. The existence of Chloroflexi, being heterotrophic bacteria, in anammox autotrophic nitrogen removal reactor, would utilize the soluble microbial products (SMP) and EPS released by the autotrophs, for metabolism (Chu et al., 2015). These results supported our findings that the inhibition of Chloroflexi by the high salinity ( $\geq 20 \mathrm{~g} \mathrm{NaCl} / \mathrm{L}$ ) as the decline of the relative abundance in this study deteriorated the sludge morphological and physical properties.

Planctomycetes, which contains all known anammox genera (Strous et al., 1999), became the most dominant phylum after the acclimatization of elevated salinity to 20 $\mathrm{g} \mathrm{NaCl} / \mathrm{L}$. There was a slight decline in the relative abundance of Planctomycetes when the salinity rose to $5 \mathrm{~g}$ $\mathrm{NaCl} / \mathrm{L}$ and $10 \mathrm{~g} \mathrm{NaCl} / \mathrm{L}$. Surprisingly, the relative abundance of this phylum at the salinity of 20,30 and $40 \mathrm{~g}$ $\mathrm{NaCl} / \mathrm{L}$ were sharply increased to $49.3 \%, 68.48 \%$ and $43.13 \%$, respectively. It seems that the inhibition of the high salinity ( $\geq 20 \mathrm{~g} \mathrm{NaCl} / \mathrm{L}$ ) was more severe to the other phyla than to Planctomycetes.

The phylum Nitrospira, affiliated to nitrite oxidizing bacteria (NOB) (Moussa et al., 2006), was detected as a predominant phylum in samples of S2 and S3. Relative to the other samples, the relative abundance of Nitrospira accounted for the highest proportion in S2. Correspondingly, at $5 \mathrm{~g} \mathrm{NaCl} / \mathrm{L}$ salinity, the stoichiometric ratios of $\mathrm{NO}_{2}^{-}-\mathrm{N}$ conversion to $\mathrm{NH}_{4}{ }^{+}-\mathrm{N}$ consumption (Rs) was higher than the theoretical ratio of 1.32 (Fig. 1d), 
indicating the occurrence of the nitrite oxidization by NOB in the studied anammox system. At $10 \mathrm{~g} \mathrm{NaCl} / \mathrm{L}$, a slight decline occurred in the relative abundance of Nitrospira, and the corresponding Rs was maintained at 1.32. Then, Nitrospira displayed a dramatic decline from $12.65 \%$ to $0.39 \%$ when the salinity reached $20 \mathrm{~g} \mathrm{NaCl} / \mathrm{L}$, even being absent from the system with the salinity over $20 \mathrm{~g} \mathrm{NaCl} / \mathrm{L}$. Therefore, it could be inferred that Nitrospira could easily survive at $5 \mathrm{~g} \mathrm{NaCl} / \mathrm{L}$, but were inhibited while the salinity elevated over $10 \mathrm{~g} \mathrm{NaCl} / \mathrm{L}$. Indeed, it has been reported that the specific nitrification rate was significantly inhibited and the nitrite accumulation occurred while the salinity exceeded $10 \mathrm{~g} / \mathrm{L} \mathrm{Cl}$ (equal to16.5 $\mathrm{g} \mathrm{NaCl} / \mathrm{L}$ ) (Chen et al. 2003).

\subsubsection{Anammox bacteria genus variations}

Analyzing microorganisms at the genus level allows a deeper understanding of the community function in the microbial ecosystem (Fig. 3b). The dominant genera as well as the distinct bacterial community were Brocadiaceae_unclassfied, Caldilineaceae_uncultured and Nitrospira. Ca. Brocadia, Ca. Kuenenia and Ca Jettenia, which affiliated with anammox bacteria, were detected at all salinities, though with a disparity of the distribution and the relative abundance. The relative abundance of $\mathrm{Ca}$. Brocadia, Ca. Jettenia and Ca. Kuenenia in S1 were at the maximum values of $3.543 \%, 0.831 \%$ and $1.176 \%$, respectively, among the all samples (Fig. 4).

After acclimatization to $5 \mathrm{~g} \mathrm{NaCl} / \mathrm{L}$ salinity for 62 days, the relative abundance of $\mathrm{Ca}$. Kuenenia encountered a slight decline by $56.7 \%$. Similarly, the relative abundance of $\mathrm{Ca}$. Brocadia and Ca Jettenia greatly declined from $3.543 \%$ to $0.255 \%$, and from $0.831 \%$ to $0.047 \%$ with decrease percentages of $93 \%$ and $94 \%$, respectively (Fig. 4). It seems that Ca. Brocadia and Ca. Jettenia were extremely sensitive to salinity. Indeed, Sonthiphand et al., (2014) explored global distributions and diversity of anammox bacteria to identify factors that influence their biogeography, and found that neither Ca. Brocadia nor Ca. Jettenia were associated with saline-related environment. Also, the $50 \%$ inhibitory concentration $\left(\mathrm{IC}_{50}\right)$ of $\mathrm{Ca}$. Jettenia was not high, being only $68 \mathrm{mM}$ for sodium chloride (equal to $4 \mathrm{~g} \mathrm{NaCl} / \mathrm{L}$ ) (Ali et al., 2015).

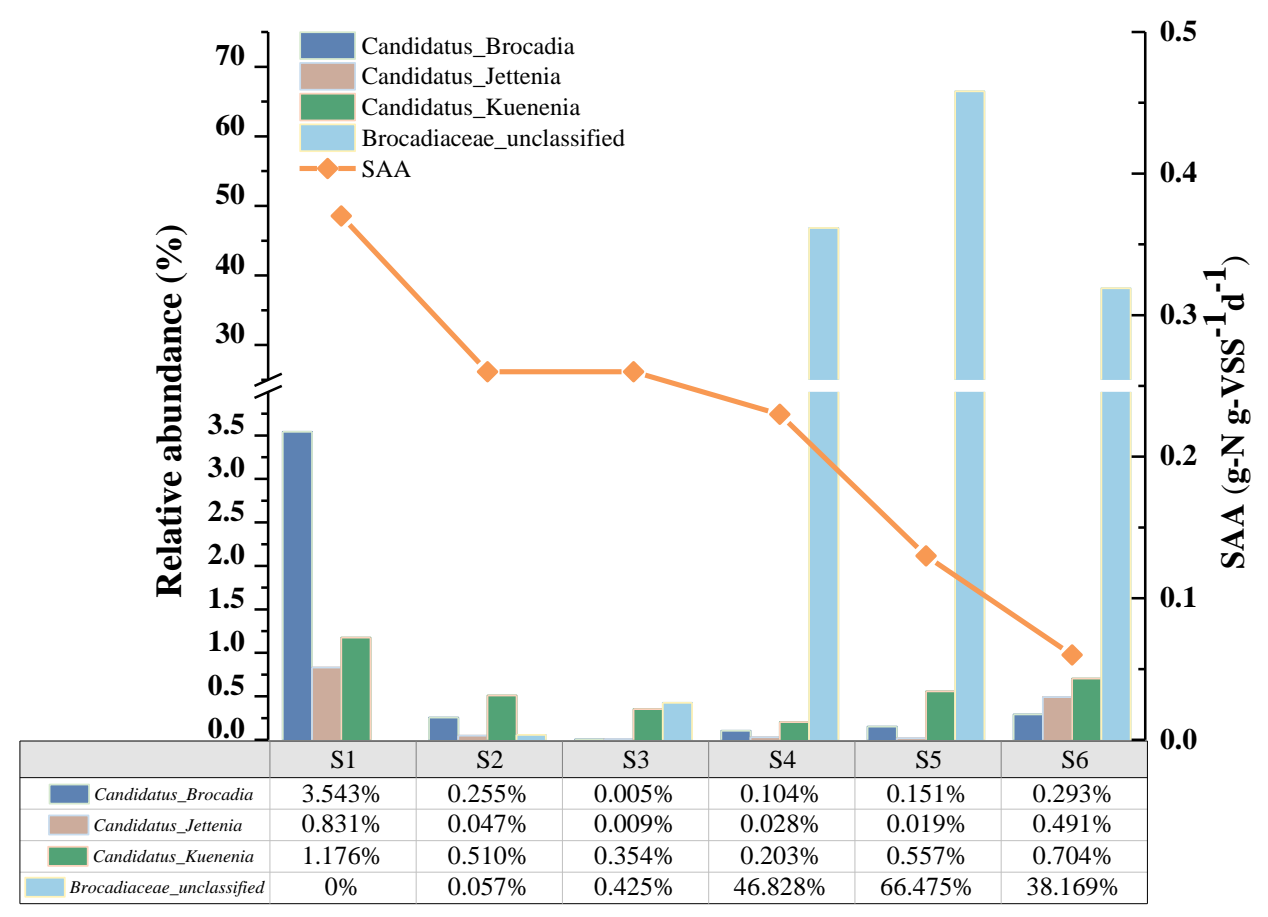

Figure 4. Changes in the relative abundance of total anammox bacteria and corresponding specific anammox activities (SAA) of sample S1 (0 g NaCl/L), S2 (5 g NaCl/L), S3 (10 g NaCl/L), S4 (20 g NaCl/L), S5 (30 g NaCl/L), S6 (40 g NaCl/L)

After the salinity increased from 5 to $10 \mathrm{~g} \mathrm{NaCl} / \mathrm{L}$, the relative abundance of these three genera of anammox bacteria continued to decline (Fig. 4). Ca. Brocadia and Ca. Jettenia almost disappeared from the system with the 
relative abundance of only $0.005 \%$ and $0.009 \%$, respectively. The relative abundance of $\mathrm{Ca}$. Kuenenia also reduced from $0.510 \%$ ( $5 \mathrm{~g} \mathrm{NaCl} / \mathrm{L})$ to $0.354 \%$ (10 $\mathrm{g} \mathrm{NaCl} / \mathrm{L})$. Fortunately, after the salinity increased above $20 \mathrm{~g} \mathrm{NaCl} / \mathrm{L}$, these three genera of anammox bacteria began to adapt to the saline environment that a rising trend of their relative abundance occurred, though they were still lower than the initial value when without $\mathrm{NaCl}$ addition. The relative abundance of $\mathrm{Ca}$. Kuenenia increased from the minimum value of $0.203 \%$ at $20 \mathrm{~g} \mathrm{NaCl} / \mathrm{L}$ to $0.557 \%$ when the salinity up to $30 \mathrm{~g} \mathrm{NaCl} / \mathrm{L}$ and continued to increase to $0.704 \%$ under $40 \mathrm{~g} \mathrm{NaCl} / \mathrm{L}$. This result was consistent with the previous study that the freshwater anammox bacteria species $C a$. Kuenenia could adapt to the salt concentration as high as $30 \mathrm{~g} \mathrm{NaCl} / \mathrm{L}$ and sustain proper anammox activity (Kartal et al. 2006). Likely, the relative abundance of $C a$. Brocadia and Ca. Jettenia increased slightly to $0.293 \%$ from $0.104 \%$ and $0.491 \%$ from $0.028 \%$ respectively, when the salinity increased from 20 to $40 \mathrm{~g} \mathrm{NaCl} / \mathrm{L}$. Similar results were also observed by Liu et al. (2009), who found that anammox bacteria affiliated with Ca. Jettenia could adapted to high salinity and the anammox activity was maintained constant after the salinity elevated to $30 \mathrm{~g}$ $\mathrm{NaCl} / \mathrm{L}$.

Interestingly, after the salinity increased from 5 to $40 \mathrm{~g}$ $\mathrm{NaCl} / \mathrm{L}$, Brocadiaceae_unclassified, which likely belong to anammox bacteria, as all of the detected anammox bacteria are affiliated with the family of Brocadiaceae, was the only dominant species in the sludge samples. As shown in Fig. 4, the relative abundance of this genus increased stepwise with the elevated salinity. Particularly, when the salinity increased to $20 \mathrm{~g} \mathrm{NaCl} / \mathrm{L}$, Brocadiaceae_unclassified increased remarkably and eventually occupied a high portion of $46.828 \%$, becoming the most dominant genus in the anammox system even though it was not detected in the initial sludge sample S1. The relative abundance of Brocadiaceae_unclassified continued to increase to a peak value of $66.475 \%$ at $30 \mathrm{~g} \mathrm{NaCl} / \mathrm{L}$, and declined slightly to $38.169 \%$ at $40 \mathrm{~g} \mathrm{NaCl} / \mathrm{L}$ salinity. It is possible that Brocadiaceae_unclassified is a novel clusters affiliated with anammox.

\subsection{Specific anammox activity of biomass}

The SAA of the biomass at the elevated salinity was evaluated using anaerobic batch tests. As shown in Fig. 4, the maximum SAA was $0.37 \mathrm{~g} \mathrm{~N} \mathrm{~g} \mathrm{VSS}^{-1} \mathrm{~d}^{-1}$ at $0 \mathrm{NaCl} \mathrm{g} / \mathrm{L}$. A stepwise decline in the SAA occurred along the increasing influent salinity, indicating that salinity had a negative impact on the anammox activity even at a low level. Compared to the initial state that without salt addition, the salinity of $5 \mathrm{~g} \mathrm{NaCl} / \mathrm{L}$ caused a $29.7 \%$ loss in SAA with the value of $0.26 \mathrm{~g} \mathrm{~N} \mathrm{~g} \mathrm{VSS}^{-1} \mathrm{~d}^{-1}$. Luckily, the SAA maintained around $0.26 \mathrm{~g} \mathrm{~N} \mathrm{~g} \mathrm{VSS}^{-1} \mathrm{~d}^{-1}$ at $20 \mathrm{~g} \mathrm{NaCl} / \mathrm{L}$ salinity through 10 $\mathrm{g} \mathrm{NaCl} / \mathrm{L}$ acclimation. When the salinity increased to $30 \mathrm{~g}$ $\mathrm{NaCl} / \mathrm{L}$, there was a notable decline in the SAA with the value of $0.13 \mathrm{~g} \mathrm{~N} \mathrm{~g} \mathrm{VSS}^{-1} \mathrm{~d}^{-1}$, being $64.9 \%$ lower than that of $0 \mathrm{~g} \mathrm{NaCl} / \mathrm{L}$. Then the SAA continued to decline to $0.06 \mathrm{~g} \mathrm{~N} \mathrm{~g}$ $V S^{-1} \mathrm{~d}^{-1}$ at $40 \mathrm{~g} \mathrm{NaCl}^{\mathrm{L}}$, indicating that the anammox activity was almost totally inhibited. The great decrease in the SAA at $40 \mathrm{~g} \mathrm{NaCl} / \mathrm{L}$ suggests that $30 \mathrm{~g} \mathrm{NaCl} / \mathrm{L}$ might be the threshold for anammox bacteria in the studied system. A similar threshold value was also reported by a previous study that anammox bacteria could retain activity at the salt concentration as high as $30 \mathrm{~g} \mathrm{NaCl} / \mathrm{L}$ (Kartal et al. 2006).

\subsection{The morphology of anammox sludge with increasing} salinity

Fig. 5 shows the morphology of anammox sludge (by SEM) along the increasing salinities $(0,5,10,30$ and $40 \mathrm{~g} \mathrm{NaCl} / \mathrm{L})$. When without salt addition, there were many cavities inside the anammox sludge, indicating that the produced $\mathrm{N}_{2}$ would be attached to the inner layers of the sludge through these cavities, which caused a decrease in the sludge density and enhanced the buoyancy as well. Strous et al., (1997) demonstrated that the nitrogen gas bubbles would become entrapped in the flocs, lifting up clusters of agglomerated beads due to a combination of clogging and intense $\mathrm{N}_{2}$ production. These factors resulted in the flotation of anammox sludge with a high wash-out of biomass. Indeed, anammox bacteria tend to being washed out of the reactor by intense gas production attached to the outer and inner layers of the sludge (Yang et al., 2011). When the salt concentration increased to 5 and $10 \mathrm{~g}$ $\mathrm{NaCl} / \mathrm{L}$, the inner layers of the granules became much densely populated, and there were fewer cavities for the transfer of nitrogen gas (Fig. 5b and c), indicating that there formatted more granules with well-defined structure under a low salinity. The granule flotation may be effectively prevented by either the capture and degradation to the intense gas bubbles of dissolved salt in 
the substance by the anammox biomass or friction and collision between the granules and the dissolved salt (Yang et al., 2011). Fernández et al., (2008) also reported that the presence of $\mathrm{NaCl}(5-10 \mathrm{~g} \mathrm{NaCl} / \mathrm{L})$ can promote the granulation of anammox sludge. By changing the sludge physical properties from flocculent to granular, the settling property of the biomass was sharply enhanced, contributed to a better effluent quality of the studied anammox system. After the salinity increased from 30 to $40 \mathrm{~g} \mathrm{NaCl} / \mathrm{L}$, the surface of the sludge became loose and rough, promoting the decaying of anammox bacterial cellular materials (Fig. $5 d$ and e). Meanwhile, the water density with high salinity was too high to maintain a good retention of the biomass inside the anammox system and a considerable washout of solids was observed by the increased turbidity of the supernatant. Bassin et al., (2012) also found an increased supernatant turbidity resulted in higher washout of biomass with the elevated salinity. The findings demonstrated that the high salt concentration ( $\geq$ $30 \mathrm{~g} \mathrm{NaCl} / \mathrm{L}$ ) would inhibit the growth and metabolism of microbes, and regulated the sludge morphology and the microbial structure as well.

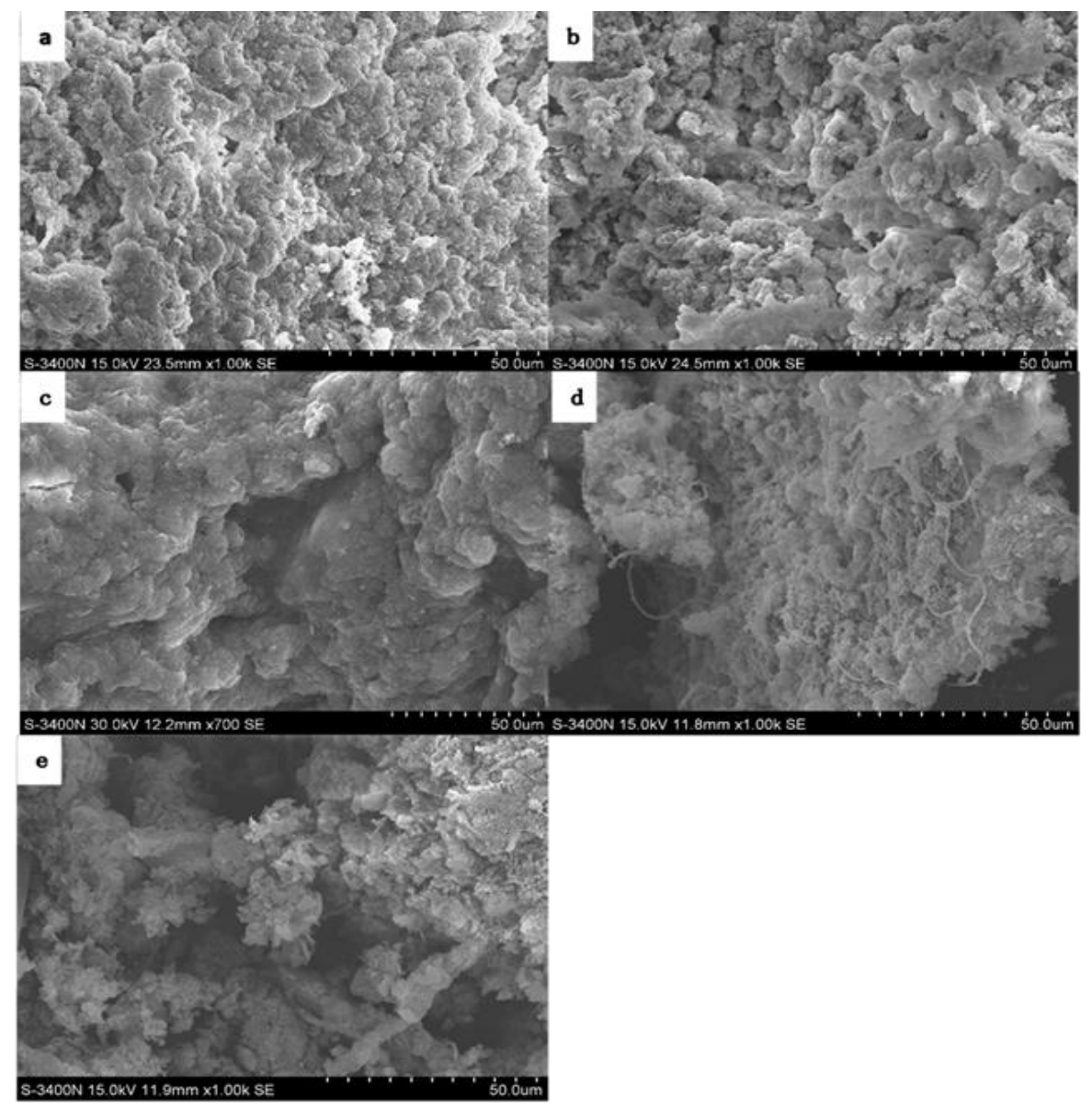

Figure 5. The morphology of the cultivated anammox sludge at different salinities (by scanning electron micrographs) (a, b, $c$ and $d$ represent the sludge samples conducted at $\mathrm{NaCl}$ salinities of at $0,5,10,30,40 \mathrm{~g} / \mathrm{L}$ respectively)

\subsection{EPS variations with increasing salinity}

EPS producing favors the survival of microorganisms under various circumstances (Liu et al., 2004). At high osmotic environment, EPS are necessary for anammox bacteria to survive in the harmful high salinity conditions. In general, EPS are composed of polysaccharide, proteins and humus. With the successful acclimatization under the relatively low salinity ( $\leq 10 \mathrm{~g} \mathrm{NaCl} / \mathrm{L}$ ), anammox bacteria generated more
EPS to resist the increasing salt stress (Fig. S1). Abbasi and Amiri, (2008) also illustrated that producing EPS is a bacterial reaction to stressful conditions of the environment (e.g. osmotic pressure). Thus, the secretion of more EPS can be a protection response for anammox bacteria under the different salt stress, ensuring the stable NRR of the anammox bioreactor.

\section{Conclusions}


The main results are summarized as follows:

1) Robust anammox performance was achieved at salinity of 0-20 $\mathrm{g} \mathrm{NaCl} / \mathrm{L}$ with the steady nitrogen removal rate approximately $0.40 \mathrm{~g} \mathrm{~N} \mathrm{~L} \mathrm{~L}^{-1} \mathrm{~d}^{-1}$ and nitrogen removal efficiency over $80 \% .30 \mathrm{~g} \mathrm{NaCl} / \mathrm{L}$ could be the threshold value of the studied anammox bioreactor.

2) Salinity is a key environmental factor regulating the anammox bacterial community. 16S rRNA high-throughput sequencing results showed that although both $\mathrm{Ca}$. Brocadia and $\mathrm{Ca}$. Jettenia were sensitive to salt, they still adapted to the high salinity environment and survived in the anammox system. Ca. Kuenenia can even adapt to the salinity up to $30 \mathrm{~g} \mathrm{NaCl} / \mathrm{L}$. Whereas, Brocadiaceae_unclassified which possibly belong to anammox bacteria, became a novel cluster coexisted with anammox bacteria at high salinities $\geq 20 \mathrm{~g} \mathrm{NaCl} / \mathrm{L}$, and likely contributed a part of the nitrogen removals.

3) The anammox granules became dense at the low salinity ( $\leq 10 \mathrm{~g} \mathrm{NaCl} / \mathrm{L}$ ) but loose and tough at high salinities ( $\geq 30$ $\mathrm{g} \mathrm{NaCl} / \mathrm{L})$. Our findings confirmed that a low level salinity would favor anammox sludge to form the well-defined granular structure while the high salinity would collapse granules.

\section{Acknowledgements}

This work was supported by the National Natural Science Foundation of China (NSFC) (nos. 51522809 and 51378370). The Fundamental Research Funds for the Central University (Tongji University) (0400219238) and the foundation of State Key Laboratory of Pollution Control and Resource Reuse (Tongji University), China (PCRRY 0400231010), are also acknowledged.

\section{References}

Abbasi A. and Amiri S. (2008), Emulsifying behavior of an exopolysaccharide produced by Enterobacter cloacae, African Journal of Biotechnology, 7(10), 1574-1576.

Adav S.S. and Lee D. (2008), Extraction of extracellular polymeric substances from aerobic granule with compact interior structure, J Hazard Mater., 154(1-3), 1120-1126.

Ali M., Oshiki M., Awata T., Isobe K., Kimura Z., Yoshikawa H., Hira D., Kindaichi T., Satoh H., Fujii T. and Okabe S. (2015), Physiological characterization of anaerobic ammonium oxidizing bacterium 'Candidatus Jettenia caeni, Environ Microbiol., 17(6), 2172-2189.

Awata T., Kindaichi T., Ozaki N. and Ohashi A. (2015), Biomass Yield Efficiency of the Marine Anammox Bacterium,
"Candidatus Scalindua sp.," is Affected by Salinity, Microbes Environ., 30(1), 86-91.

Bassin J.P., Kleerebezem R., Muyzer G., Rosado A.S., van Loosdrecht M.C. and Dezotti M. (2012), Effect of different salt adaptation strategies on the microbial diversity, activity, and settling of nitrifying sludge in sequencing batch reactors, Appl Microbiol Biotechnol., 93(3), 1281-1294.

Bossier P. and Verstraete W. (1996), Triggers for microbial aggregation in activated sludge?, Applied Microbiol Biot., 45(1-2), 1-6.

Chen G.H., Wong M.T., Okabe S. and Watanabe Y. (2003), Dynamic response of nitrifying activated sludge batch culture to increased chloride concentration, Water Res., 37(13), 3125-3135.

Chu Z., Wang K., Li X., Zhu M., Yang L. and Zhang J. (2015), Microbial characterization of aggregates within a one-stage nitritation-anammox system using high-throughput amplicon sequencing, Chem Eng J., 262, 41-48.

Claesson M.J., Wang Q., O'Sullivan O., Greene-Diniz R., Cole J.R., Ross R.P. and O'Toole P.W. (2010), Comparison of two nextgeneration sequencing technologies for resolving highly complex microbiota composition using tandem variable $16 \mathrm{~S}$ rRNA gene regions, Nucleic Acids Res., 38(22), 1-13.

Dapena-Mora A., Campos J.L., Mosquera-Corral A. and Méndez R. (2006), Anammox process for nitrogen removal from anaerobically digested fish canning effluents, Water Science and Technology, 53(12), 265-274.

Dapena-Mora A., Campos J.L., Mosquera-Corral A., Jetten M. and Méndez R. (2004), Stability of the ANAMMOX process in a gaslift reactor and a SBR, J Biotechnol., 110(2), 159-170.

Din Er A.R. and Kargi F. (2001), Performance of rotating biological disc system treating saline wastewater, Process Biochem., 36(8-9), 901-906.

Fernández I., Vázquez-Padín J.R., Mosquera-Corral A., Campos J.L. and Méndez R. (2008), Biofilm and granular systems to improve Anammox biomass retention, Biochem Eng J., 42(3), 308-313.

Glenn T.C. (2011), Field guide to next-generation DNA sequencers, Mol Ecol Resour., 11(5), 759-769.

Hu M., Wang X., Wen X. and Xia Y. (2012), Microbial community structures in different wastewater treatment plants as revealed by 454-pyrosequencing analysis, Bioresource Technol., 117, 72-79.

Jin R., Yang G., Yu J. and Zheng P. (2012), The inhibition of the Anammox process: A review, Chem Eng J., 197, 67-79. 
Kartal B., Koleva M., Arsov R., van der Star W., Jetten M.S.M. and

Strous M. (2006), Adaptation of a freshwater anammox population to high salinity wastewater, J Biotechnol., 126(4), 546-553.

Kartal B., Kuenen J.G. and van Loosdrecht M.C. (2010), Engineering. Sewage treatment with anammox, Science, 328(5979), 702-703.

Kindaichi T., Yuri S., Ozaki N. and Ohashi A. (2012), Ecophysiological role and function of uncultured Chloroflexi in an anammox reactor, Water Sci Technol., 66(12), 2556-2561.

Liu C., Yamamoto T., Nishiyama T., Fujii T. and Furukawa K. (2009), Effect of salt concentration in anammox treatment using non woven biomass carrier, J Biosci Bioeng., 107(5), 519-523.

Liu H. and Fang H.H.P. (2002), Extraction of extracellular polymeric substances (EPS) of sludges, J Biotechnol., 95(3), 249-256.

Liu Y., Liu Y. and Tay J. (2004), The effects of extracellular polymeric substances on the formation and stability of biogranules, App/ Microbiol Biot., 65, 143-148.

Miura Y., Watanabe Y. and Okabe S. (2007), Significance of Chloroflexi in performance of submerged membrane bioreactors (MBR) treating municipal wastewater, Environ Sci Technol., 41(22), 7787-7794.

Moussa M.S., Sumanasekera D.U., Ibrahim S.H., Lubberding H.J., Hooijmans C.M., Gijzen H.J. and van Loosdrecht M.C. (2006), Long term effects of salt on activity, population structure and floc characteristics in enriched bacterial cultures of nitrifiers, Water Res., 40(7), 1377-1388.

Nakajima J., Sakka M., Kimura T., Furukawa K. and Sakka K. (2008), Enrichment of anammox bacteria from marine environment for the construction of a bioremediation reactor, Appl Microbiol Biot., 77(5), 1159-1166.

Panswad T. and Anan C. (1999), Specific oxygen, ammonia, and nitrate uptake rates of a biological nutrient removal process treating elevated salinity wastewater, Bioresource Technol., 70(3), 237-243.

Schloss P.D., Westcott S.L., Ryabin T., Hall J.R., Hartmann M., Hollister E.B., Lesniewski R.A., Oakley B.B., Parks D.H. and Robinson C.J. (2009), Introducing mothur: open-source, platform-independent, community-supported software for describing and comparing microbial communities, Appl Environ Microb., 75(23), 7537-7541.

Sonthiphand P., Hall M.W. and Neufeld J.D. (2014), Biogeography of anaerobic ammonia-oxidizing (anammox) bacteria, Front Microbiol., 5, 1-14.
Strous M., Kuenen J.G. and Jetten M.S. (1999), Key physiology of anaerobic ammonium oxidation, Appl Environ Microbiol., 65(7), 3248-3250.

Strous M., Van Gerven E., Zheng P., Kuenen J.G. and Jetten M.S. (1997), Ammonium removal from concentrated waste streams with the anaerobic ammonium oxidation (anammox) process in different reactor configurations, Water Res., 31(8), 1955-1962.

Thamdrup B. and Dalsgaard T. (2002), Production of N2 through anaerobic ammonium oxidation coupled to nitrate reduction in marine sediments, Appl Environ Microb., 68(3), 1312-1318.

Uygur A. (2006), Specific nutrient removal rates in saline wastewater treatment using sequencing batch reactor, Process Biochem., 41(1), 61-66.

Van Hulle S.W.H., Vandeweyer H.J.P., Meesschaert B.D., Vanrolleghem P.A., Dejans P. and Dumoulin A. (2010), Engineering aspects and practical application of autotrophic nitrogen removal from nitrogen rich streams, Chem Eng J., 162(1), 1-20.

Venter J.C., Remington K., Heidelberg J.F., Halpern A.L., Rusch D., Eisen J.A., Wu D., Paulsen I., Nelson K.E. and Nelson W. (2004), Environmental genome shotgun sequencing of the Sargasso Sea, Science, 304(5667), 66-74.

Wang Q., Garrity G.M., Tiedje J.M. and Cole J.R. (2007), Naive Bayesian classifier for rapid assignment of rRNA sequences into the new bacterial taxonomy, Appl Environ Microb., 73(16), 5261-5267.

Xing B., Guo Q., Yang G., Zhang J., Qin T., Li P., Ni W. and Jin R. (2015), The influences of temperature, salt and calcium concentration on the performance of anaerobic ammonium oxidation (anammox) process, Chem Eng J., 265, 58-66.

Yang J., Zhang L., Hira D., Fukuzaki Y. and Furukawa K. (2011), Anammox treatment of high-salinity wastewater at ambient temperature, Bioresource Technol., 102(3), 2367-2372.

Yi Y., Yong H. and HuiPing D. (2011), Effect of Salt on Anammox Process, Procedia Environmental Sciences, 10, 2036-2041. 